Review Article

\title{
Complementary and Alternative Treatment Methods for Allergic Rhinitis
}

\author{
Dr. Kamlesh Kumar Dubey ${ }^{*}$ \\ Melaka-Manipal Medical College, Jalan Padang Jambu, Bukit Baru, 75150 Melaka, Malaysia \\ *Corresponding Author \\ Dr. Kamlesh kumar dubey
}

Article History

Received: 15.01 .2020

Accepted: 22.01 .2020

Published: 27.01.2020

\begin{abstract}
Introduction: Incidence of allergic rhinitis is increasing each year. Primary mood of treatemnt is pharmacotherapy, which is associated with side effects because of long term use. Long term use of pharmacotherapy involves cost expenditure also. Use of complementary and alternative form of treatment methods increasing in western countries but widely prevelent in Asian countries like tradional indian medicine, traditonal chinese medicine, tradional japanese medicine. For wider acceptance in general public more studies focusing on mechanism of action of these complementary and alternative medicines is required with finding any adverse effetcs. Current article aimed to search for articles available in literature both online and offline.
\end{abstract}

Keywords: allergic, pharmacotherapy, literature.

\section{INTRODUCTION}

Allergic rhinitis (AR), a nasal symptomatic disorder induced after allergen exposure, is characterized by nasal congestion and discharge, sneezing, and nasal itching [1], and it is estimated to affect about 1.4 billion people globally and continues to be on the rise [2]. AR causes major illness and disability worldwide and reduces the quality of life and productivity regardless of ethnicity, gender, and age [3]. Conventional medical treatments for AR include H1antihistamines, leukotriene antagonists, glucocorticosteroids, anticholinergics, decongestants, and specific immunotherapy [4]. Despite the clinical effects of these conventional treatments, their adverse reactions cause concern. Treatment combining complementary and alternative medicine improves clinical effects and reduces the incidence of adverse reactions [5]. Complementary and integrative medicine therapies are frequently used to treat various chronic diseases such as allergic rhinitis (AR) [6]. One study from USA found that nearly $50 \%$ of American adults experiencing asthma or rhinosinusitis have tried CIM treatments [7]. This article aims to discuss in brief some of the common form of complementary and alternative medicine and treatment forms for therapies for allergic rhinitis (AR).

\section{Data search}

We searched the electronic database for available till Dec 2019 on PubMed, Embase, MEDLINE, Springer, Proquest, Cochrane Library.

\section{Common forms of complementary and integrative treatments options for allergic rhinitis Nonspecific Acupuncture}

Many studies have been able to show improvement in symptoms of allergic rhinitis after sessions for acupuncture. The evidence for the effectiveness of acupuncture for the symptomatic treatment or prevention of AR is mixed. The results for seasonal AR failed to show specific effects of acupuncture. For perennial AR, results provide suggestive evidence of the effectiveness of acupuncture [8]. In a random study done on 5237 patients at Charité University Medical Center, Berlin, Germany. During this large nonblinded study patients were evaluated on Rhinitis Quality of Life (RQLQ) questionnaire at baseline and after 3 and 6 months. Results of this study showed positive improvement in symptoms of allergic rhinitis clinically and that was persistent [9].

Copyright @ 2020: This is an open-access article distributed under the terms of the Creative Commons Attribution license which permits unrestricted use, distribution, and reproduction in any medium for non commercial use (NonCommercial, or CC-BY-NC) provided the original author and source are credited. 


\section{Acupuncture at sphenopalatine ganglion acupoint}

Few studies are available in literature on acupuncture at sphenopalatine acupoint with varied results. Most of these studies are from China. Earliest report of a study on acupuncturing of sphenopalatine ganglion for treatment of rhinitis symptoms was published in Beijing journal of Chinese Medicine in 1990 [10]. Symptomatic relief and antiinflammatory mechanism in this form of treatment may be by affecting the vagus nerve supply to secreting glands of nasal cavity which are hyperfunctioning during inflammation. So, this sphenopalatine ganglion acupuncture prevents the development of symptoms of allergic rhinitis (AR) by preventing the interaction between vagus nerve and macrophages [9]. An article published in Journal of clinical otorhinolaryngology head and neck surgery 2011 elaborate a large study conducted on 130,000 Chinese patients found definite improvements in nasal symptoms of allergic rhinitis and quality of life after sphenopalatine ganglion acupoint acupuncture, a technique developed by a Chinese otorhinolaryngologist [11]. However, it has been limited by the lack of evidence in evidence-based medicine to evaluate the efficiency of acupuncturing SGA alone in the treatment for AR [12].

\section{Ear acupressure}

One treatment form still unproven is ear acupressure. Study from WHO Collaborating Centre for Traditional Medicine, RMIT University, Australia by Zhang et al. found that Ear- acupressure was more effective than herbal medicine, as effective as body acupuncture or antihistamine for short- term effect, but it was more effective than antihistamine for long- term effect [12]. Due to poor quality of research this from of treatment is not recommended for symptomatic relief of allergic rhinitis.

\section{Herbal therapies: Overview of common herbal treatment options for allergic rhinitis (AR) [6]:}

\begin{tabular}{|c|c|c|c|}
\hline Therapy & Ingredient & Mechanism of action & Evidence \\
\hline Local Honey & Local pollen & $\begin{array}{l}\text { Allows the body to build up } \\
\text { tolerance to offending allergens }\end{array}$ & No supporting evidence \\
\hline Butterbur extract & Petasin & $\begin{array}{l}\text { Antileukotriene biosynthesis } \\
\text { and antihistamine properties }\end{array}$ & $\begin{array}{l}\text { Studies displayed butterbur's efficacy } \\
\text { with several antihistaminic drugs }\end{array}$ \\
\hline Spirulina & $\begin{array}{l}\text { Dried blomass of } \\
\text { Arthrospira platensis }\end{array}$ & $\begin{array}{l}\text { Inhibition of mast cell release } \\
\text { of histamine and possible } \\
\text { increased IFN- } \gamma \text { levels }\end{array}$ & $\begin{array}{l}\text { Randomized double blind study showed } \\
\text { significant reduction in IL- } 4 \text { levels }\end{array}$ \\
\hline Bioflavonoid & Quercetin & $\begin{array}{l}\text { Inhibits basophil and mast cell } \\
\text { degranulation }\end{array}$ & $\begin{array}{l}\text { Twice as effective as sodium cromolyn } \\
\text { in reducing LT production }\end{array}$ \\
\hline Flavonolignan & Silymarin & Stabilizes cell membrane & $\begin{array}{l}\text { Addition of silymarin to cetirizine } \\
\text { improved clinical symptoms }\end{array}$ \\
\hline $\begin{array}{l}\text { Saccharomyces } \\
\text { cerevisiae }\end{array}$ & Oral yeast & Unknown & Showed reduction in nasal congestion \\
\hline $\begin{array}{l}\text { Baikal skullcap } \\
\text { root }\end{array}$ & $\begin{array}{l}\text { Scutellaria } \\
\text { baicalensis }\end{array}$ & Unknown & Decreased serum IgE and IL-5 levels \\
\hline Soy sauce & $\begin{array}{l}\text { Shoyu } \\
\text { polysaccharides }\end{array}$ & Unknown & $\begin{array}{l}\text { Reduced runny nose, sore throat, and } \\
\text { itchy eyes }\end{array}$ \\
\hline Xin-yi-san & $\begin{array}{l}\text { Unknown Chinese } \\
\text { herb }\end{array}$ & Unknown & $\begin{array}{l}\text { Improvements in nasal symptoms and } \\
\text { congestion, suppressed serum IgE } \\
\text { levels, and increased IL-10 and IL-8 } \\
\text { levels }\end{array}$ \\
\hline
\end{tabular}

\section{Use of Honey in Allergic rhinitis}

Most recent publication is from Malaysia published in 2013. Authors studied ingestion of large dose of honey in 40 patients diagnosed with AR for relief of rhinitis symptoms. They used 1 gm honey/kg body weight per day in divided doses, all patients in this study were on antihistaminic Loratadine same time. There was marked improvement in patients' complaints [14]. Honeys' mechanism of action has been suggested by few studies from Japan. Authors showed the antiallergic mechanism of honey by inhibiting $\operatorname{IgE}$ mediated mast cell activation both in vivo and in vitro in animal studies $[15,16]$. Similar study on royal jelly which is an important food of queen bee found to modify symptoms of allergic rhinitis positively and relief to patients [17]. In this study researchers studied the mechanism of antiallergic effects of royal jelly. Treatment with royal jelly decreased sneezing on toluene 2,4-disscyanate (TDI) stimulated rats. One reason we can give for relief of symptoms could be desensitization to aeroallergen by feeding honey to patients. Study by Saarinen and others showed that regularly giving oral birch pollen honey to patients known to be allergic to birch pollen, led to less severe symptoms and requirement of anti-allergy medications reduced [18] mechanism here is desensitization to birch pollen by giving oral birch pollen honey. Many studies have suggested reduction in risk to allergic reaction to known food and environmental allergen if exposed to that allergen early in life [19-21]. 


\section{Soy sauce for management of allergic rhinitis symptoms}

Japanese researchers have come up with usefulness of soy sauce-based products in management of allergic rhinitis. Kobayashi and colleague study determined whether oral supplementation of SPS is an effective intervention for patients with seasonal allergic rhinitis. In an 8-week randomized, double-blind, placebo-controlled parallel group study, patients with mild seasonal allergic rhinitis were treated with $600 \mathrm{mg}$ of SPS $(n=25)$ or placebo $(n=26)$ each day. After 4 weeks of treatment with SPS, symptom scores such as sneezing, nasal stuffiness, and hindrance of daily life were significantly different $(\mathrm{P}<0.05)$ from those in placebo-treated groups. The total symptom score, calculated from the sum of individual scores, showed a significant difference $(\mathrm{P}<0.05)$ between the 2 groups after $4-8$ weeks. On nasal examination by the investigator, the colour of the inferior turbinate in SPS-treated patients was significantly different $(\mathrm{P}<0.05)$ from that in placebo-treated patients between weeks 4 and 8 , and the nasal symptom scores for colour of inferior turbinate, watery discharge, and state of sniffles were also significantly different $(\mathrm{P}<0.05)$ from those in the placebo-treated group after 8 weeks [22]. Authors concluded that soy sauce as daily food useful in improving quality of life in seasonal allergic rhinitis.

\section{Phyto therapy/Herbal medicines for managing allergic rhinitis (AR)}

While searching for research published on use of Phytotherapy for managing allergic rhinitis symptoms, we found more than 250 articles published focused on using herbal and plant-based products. Study of 2017 from Japan published in 2017 in Allergology International [23],has described usefulness of Phyto-therapy by using common herbs in descending order Ten-Cha (Rubus Suavissimus) 38.8\%, Chameleon plant tea (Houttuynia cordata) 3.9\%, Guava tea (Psidium guajava) 3.2\%, Japanese green tea (Camellia sinensis) 2.3\%, Japanese persimmon tea (Diospyros kaki) $2.1 \%$ Gymnema tea (Gymnema sylvestre) 1.0\%, Herb tea (unclear content) 4.7\% and found patients with seasonal allergic rhinitis (SAR) more preferred to use Phyto-therapy for relief of symptoms. Research published in Saudi Med J January 2019 issue described use of various plant-based products for symptomatic improvement in allergic rhinitis which included most commonly black seed (Nigella sativa) followed by Anise (Pimpinella anisum), guava (Psidium guajava), ginger (Zingiber officinale and thymus (Thymus vulgaris). Still we need more research before coming to the confirmed mechanism action. Islam $\mathrm{R}$ and colleagues studied the role of wild grape extracts (WGE) in relieving symptoms of allergic rhinitis. Authors investigated the effect of WG hot water extract (WGE) on the signaling pathways for PKC $\delta$ mediated H1R and NFAT-mediated IL-9 gene expressions. WGE suppressed histamine/PMA-induced H1R gene upregulation in HeLa cells. Toluene-2,4-diisocyanate (TDI)-induced H1R mRNA elevation in TDI-sensitized rats was also suppressed by WGE treatment. Treatment with WGE in combination with Awa-tea, suppresses NFAT signalingmediated IL-9 gene, markedly alleviated nasal symptoms [25].

\section{Ayurvedic treatment methods for allergic rhinitis}

Ayurveda is Indian system of medicine. According one research published in 2015 ayurvedic medicine practitioners Shravan Kumar Sahu and colleagues found similarities in etiological factors and clinical features. Authors suggested that Allergic Rhinitis may be correlated with Vataja Pratishyaya and should be treated accordingly considering breakdown of the pathogenesis on top priority. Such treatment should incorporate holistic approach i.e. three tier treatment approach viz. 1. Introduction of local treatment as Snehana Nasya [26]. In Ayurveda system of medicine, we can identify various medicinal preparations mentioned under Bhaishajya Kalpana [15]. Decoctions (kashaya), vati (pills), powders (churna), oils (taila), and arishta-asava (fermented preparations) are few examples for them. It would worth mentioning one research published in 2019 by Srilankan researchers on Tamalakyadi decoction (TD) containing 12 ingredients (TMD12). Which is an effective herbal decoction and found have antioxidants properties, has been used for allergic rhinitis since long time [27]. Aller-7 is a mixture of seven Indian herbs (Albizia lebbeck, Terminalia chebula, Terminalia bellerica, Phyllanthus emblica, Piper nigrum, Piper longum, and Zingiber officinale). In vitro studies examining the mixture demonstrated antihistaminic and anti-inflammatory properties and were found to be equivalent to cetirizine [28]. Ayurvedic treatment methods include use of plant and herbs derived oils.

\section{Homeopathy for allergic rhinitis}

Several trials study is available in literature to know and prove efficacy of homeopathic medicines as a form of treatment method to manage symptoms of allergic rhinitis (AR). Gruendling et all published an article in 2012. Authors found wide acceptance and increase demand in society for homeopathy as a complementary form of treatment for allergic rhinitis. Homeopathy treatment involves both the treatment options available currently in management of allergic rhinitis: (1) relief of symptoms, (2) supporting the immune system of patients [29]. A multicentre observational study conducted in Germany from February 2012 to July 2013 involving 59 therapists with treatment focus on seasonal allergic rhinitis (SAR). After evaluation of data collected from 123 patients, authors found relief in symptoms from seasonal allergic rhinitis (SAR) as well as improvement in quality of life in the patients [30]. 


\section{Saline Nasal irrigation}

Systemic review by Hermelingmeier KE et al. in 2012 found Nasal irrigation with saline solution results in the improvement of symptoms, quality of life, and better mucociliary clearance time (MCT). Authors further concluded that consumption of antiallergic medication can also be decreased. Nasal irrigation represents a safe and inexpensive, nonpharmacologic form of treatment [32]. Cochrane systemic review by Karen Head and colleagues for randomized controlled trial (RCT) comparing nasal irrigation, delivered by any means and with any volume, tonicity, and alkalinity, with (a) no saline nasal irrigation or (b) other pharmacological treatments in adult and children with allergic rhinitis. Authors concluded that saline nasal irrigation reduced patient reported disease severity at up to three months with no report of adverse effects $n$ both adults and children with allergic rhinitis [33].

\section{CONCLUSION}

We all know and reported in various studies incidence of allergic rhinitis and other allergic manifestation has increased in society. There are guidelines for management of allergic rhinitis related complaints as proposed by Allergic Rhinitis and its Impact on Asthma (ARIA), American Academy of Otolaryngology-Head and Neck Surgery endorsed by American Academy of Family Physicians (AAFP), Joint Task Force on Practice Parameters (JTFPP) and British Society for Allergy and Clinical Immunology (BSACI). Mainstay of treatment in all proposed guidelines is pharmacotherapy. Pharmacotherapy comes with issues involved, which include cost of medicines, side effects \& adverse effects and compliance factors. These complementary and alternative form of treatment method is in use for thousands of years of known human kind history. There is literature available to suggest benefit and relief in symptoms of allergic rhinitis and improvement in quality of life after using these complementary and alternative medicines. Studies on side effects and efficacy rate is insufficient. That's why further research and studies in complementary and alternative treatment methods for allergic rhinitis is need of hour.

\section{REFFERENCE}

1. Bousquet, J., Khaltaev, N., Cruz. A. A. (2008). "Allergic rhinitis and its impact on asthma (ARIA) 2008update (in collaboration with the World Health Organization, GALEN and Aller Gen)," Allergy, 86, 8-160.

2. Schwindt, C. D., \& Settipane, R. (2012). "Allergic rhinitis (AR) is now estimated to affect some 1.4 billion people globally and continues to be on the rise. Editorial," American Journal of Rhinology \& Allergy, (26), S1.

3. Camelo-Nunesand, I.C., Sol'e, D.(2010). "Allergic rhinitis: Indicators of quality of life," Jornal Brasileiro de Pneumologia, 36(1),124-133,

4. Bro zek, J. L., Bousquet, J., Baena-Cagnaniet, C. E. (2010). “Allergic Rhinitis and its Impact on Asthma (ARIA) guidelines: 2010 revision," The Journal of Allergy and Clinical Immunology, 126(3), 466-476.

5. SchAeFeR, T., Riehle, A., Wichmann, H. E., \& Ring, J. (2002). Alternative medicine in allergies-prevalence, patterns of use, and costs. Allergy, 57(8), 694-700.

6. Garbo, G., Tessema, B., \& Brown, S. M. (2013). Complementary and integrative treatments: allergy. Otolaryngologic Clinics of North America, 46(3), 295-307.

7. Resnick, E. S., Bielory, B. P., \& Bielory, L. (2008). Complementary therapy in allergic rhinitis. Current allergy and asthma reports, 8(2), 118-125.

8. Lee, M. S., Pittler, M. H., Shin, B. C., Kim, J. I., \& Ernst, E. (2009). Acupuncture for allergic rhinitis: a systematic review. Annals of Allergy, Asthma \& Immunology, 102(4), 269-279.

9. Brinkhaus, B., Witt, C. M., Jena, S., Liecker, B., Wegscheider, K., \& Willich, S. N. (2008). Acupuncture in patients with allergic rhinitis: a pragmatic randomized trial. Annals of Allergy, Asthma \& Immunology, 101(5), 535-543.

10. Li, X. W., \& Tian, Z. P. (1990). A preliminary summary of the treatment on rhinitis puncturing sphenopalatine ganglion. Beijing Chin Med, 9(4), 36-8.

11. $\mathrm{Li}, \mathrm{X}$. (2011). The mechanism analysis of treating nasal disease by sphenopalatine ganglion (acupoint "ZhiBi 3") stimulation with acupuncture needle and an introduction to the relevant needling method. J Clin Otorhinolaryngol Head Neck Surg, 5, 193.

12. Fu, Q., Zhang, L., Liu, Y., Li, X., Yang, Y., Dai, M., \& Zhang, Q. (2019). Effectiveness of Acupuncturing at the Sphenopalatine Ganglion Acupoint Alone for Treatment of Allergic Rhinitis: A Systematic Review and MetaAnalysis. Evidence-Based Complementary and Alternative Medicine, 2019.

13. Zhang, C. S., Yang, A. W., Zhang, A. L., Fu, W. B., Thien, F. C., Lewith, G., \& Xue, C. C. (2010). Ear- acupressure for allergic rhinitis: a systematic review. Clinical Otolaryngology, 35(1), 6-12.

14. Asha'ari, Z. A., Ahmad, M. Z., Din, W. S. J. W., Hussin, C. M. C., \& Leman, I. (2013). Ingestion of honey improves the symptoms of allergic rhinitis: evidence from a randomized placebo-controlled trial in the East Coast of Peninsular Malaysia. Annals of Saudi medicine, 33(5), 469-475.

15. Ishikawa, Y., Tokura, T., Nakano, N., Hara, M., Niyonsaba, F., Ushio, H., \& Ogawa, H. (2008). Inhibitory effect of honeybee-collected pollen on mast cell degranulation in vivo and in vitro. Journal of medicinal food, 11(1), 14-20. 
16. Ishikawa, Y., Tokura, T., Ushio, H., Niyonsaba, F., Yamamoto, Y., Tadokoro, T., \& Okumura, K. (2009). Lipidsoluble components of honeybee- collected pollen exert antiallergic effect by inhibiting IgE- mediated mast cell activation in vivo. Phytotherapy research, 23(11), 1581-1586.

17. Shaha, A., Mizuguchi, H., Kitamura, Y., Fujino, H., Yabumoto, M., Takeda, N., \& Fukui, H. (2018). Effect of Royal Jelly and Brazilian Green Propolis on the Signaling for Histamine H1 Receptor and Interleukin-9 Gene Expressions Responsible for the Pathogenesis of the Allergic Rhinitis. Biological and Pharmaceutical Bulletin, 41(9), 14401447.

18. Saarinen, K., Jantunen, J., \& Haahtela, T. (2011). Birch pollen honey for birch pollen allergy-a randomized controlled pilot study. International archives of allergy and immunology, 155(2), 160-166.

19. Burks, A. W., Laubach, S., \& Jones, S. M. (2008). Oral tolerance, food allergy, and immunotherapy: implications for future treatment. Journal of Allergy and Clinical Immunology, 121(6), 1344-1350.

20. Ege, M. J., Bieli, C., Frei, R., van Strien, R. T., Riedler, J., Üblagger, E., \& Pershagen, G. (2006). Prenatal farm exposure is related to the expression of receptors of the innate immunity and to atopic sensitization in school-age children. Journal of Allergy and Clinical Immunology, 117(4), 817-823.

21. Von Hertzen, L., \& Haahtela, T. (2006). Disconnection of man and the soil: reason for the asthma and atopy epidemic?. Journal of Allergy and Clinical Immunology, 117(2), 334-344.

22. Kobayashi, M., Matshushita, H., Tsukiyama, R., Saito, M., Sugita, T. Soyu polysaccharides from soy sauce improves quality of life for patients with seasonal allergic rhinitis: A double-blind placebo controlled clinical study.

23. Syuji, Y., Yoshitaka, O., Daiju, S. (2017). Complementary and alternative medicine for allergic rhinitis in Japan. Allergology International; 66:425-431.

24. Abdulrahman, E., Koshak. (2019). Prevalence of herbal medicines in patients with chronic allergic disorders in Western Saudi Arabia. Saudi Med J, 40(4):391-396.

25. Islam, R., Mizuguchi, H., Shaha, A., Nishida, K., Yabumoto, M. (2018). Effect of wild grape on the signaling of histamine $\mathrm{H}_{1}$ receptor gene expression responsible for the pathogenesis of allergic rhinitis. J Med Invest, 65(3, 4):242-250.

26. Shravan, K.U., Dhiman, K.S., Vaghela, D.B., Shweta, M. (2016). Allergic rhinitis in ayurvedic perspective. World Journal of Pharmaceutical Research, 4(8): 2192-2198.

27. Dahanayake, J. M., Perera, P. K., Galappatty, P., Perera, H. D. S. M., \& Arawwawala, L. D. A. M. (2019). Comparative Phytochemical Analysis and Antioxidant Activities of Tamalakyadi Decoction with Its Modified Dosage Forms. Evidence-Based Complementary and Alternative Medicine, 2019.

28. Sumit, S. (2017). Unproven/Alternative methods of treating allergic rhinitis. Global Journal of Otolaryngology, 3(1).

29. Gründling, C., Schimetta, W., \& Frass, M. (2012). Real-life effect of classical homeopathy in the treatment of allergies: A multicenter prospective observational study. Wiener Klinische Wochenschrift, 124(1-2), 11-17.

30. Ernst, E. (2011). Homeopathic Galphimia glauca for hay fever: a systematic review of randomised clinical trials and a critique of a published meta- analysis. Focus on Alternative and Complementary Therapies, 16(3), $200-203$.

31. Trompetter, I., Lebert, J., \& Weiß, G. (2015). Homeopathic complex remedy in the treatment of allergic rhinitis: results of a prospective, multicenter observational study. Complementary Medicine Research, 22(1), 18-23.

32. Hermelingmeier, K. E., Weber, R. K., Hellmich, M., Heubach, C. P., \& Mösges, R. (2012). Nasal irrigation as an adjunctive treatment in allergic rhinitis: a systematic review and meta-analysis. American journal of rhinology \& allergy, 26(5), e119-e125.

33. Karen, H., Kornkiat, S., Simon, G. (2018). Saline irrigation for allergic rhinitis. Cochrane Database of Systemic Reviews, 6. CD012597. 